\title{
A new species of Merxmuellera (Arundineae, Poaceae) from South Africa
}

\author{
N.P. BARKER* and R.P. ELLIS**
}

ABSTRACT

Merxmuellera setacea N.P. Barker from the south-western Cape. South Africa, is formally described. Descriptions of the morphology and leat anatomy, in transectional and surface view, as observed under the light- and scanning electron microscope are given. Comparisons between this taxon and other southern African arundinoid species are made on the basis of morphological and anatomical observations. While the morphology of $M$. setacea is in keeping with the generic limits of Merxmuellera Conert. the leaf blade anatomy appears to be intermediate between Merxmuellera, Pentameris Beauv. and Pentaschistis (Nees) Spach

\section{UITTREKSEL}

Merrmuellera setacea N.P. Barker uit die Suidwes-Kaap. Suid-Afrika, word formeel beskryf. Beskrywings van die morfologie en blaaranatomie, in deursnee- en oppervlakaansig. soos met die ligmikroskoop en aftaselektronmikroskoop waargeneem. word gegee. Hierdie takson word op grond van morfologiese en anatomiese waarnemings met ander arundinoiede spesies van suidelike Afrika vergelyk. Die morfologie van $M$. setacea strook met die genusafbakening van Merxmuellera Conert. maar die anatomie van die blaarskyf is skynbaar intermediêr tussen Merxmuellera. Pentameris Beauv. en Pentaschistis (Nees) Spach.

\section{Merxmuellera setacea $N . P$. Barker, sp. nov.}

Merxmuellera sp. (Ellis 5500) in Gibbs Russell et al.:218 (1990).

Vaginae foliorum glabrae. basin versus ventricosae: laminae folium usque ad $150 \mathrm{~mm}$ longae, setaceae. pungentes; lemma praeter caespem unum submarginalem pilorum alborum in utraque lato. in circa tertia parte longitudinis corporis lemmae situm. glabra.

A caespitose, perennial grass. Rhizomes producing closely spaced buds which develop into bulb-like structures as they become covered in thickened, swollen leaf sheath bases. Flowering culms erect. $0.73-1.0 \mathrm{~m}$ tall. usually with three nodes. Leaves: sheaths glabrous to somewhat glossy when young, bearded at the mouth, basally swollen. thickened and somewhat pithy: ligule a fringe of hairs up to $0,75 \mathrm{~mm}$ long: leaf blades permanently infolded, setaceous, glabrous below, up to $150 \mathrm{~mm}$ long with pungent apices. Inflorescence contracted, shortly branched, lanceolate panicle up to $150 \mathrm{~mm}$ long, with 50-100 (or more) spikelets. Spikelets 3(-4)-flowered, $12-15 \mathrm{~mm}$ long (excluding aw $\mathrm{ns}), 4-6 \mathrm{~mm}$ wide, uppermost floret sometimes rudimentary; glumes $8-13 \mathrm{~mm}$ long, as long as or longer than the body of the proximal floret, 1-nerved, straw-coloured to pale greenish yellow to olive, with keel sometimes tinged dark purple, glabrous and thinly papery: lemma $8.5-13.0 \mathrm{~mm}$ long. bilobed. lobes attenuating into a $5 \mathrm{~mm}$ long lateral bristle. glabrous except for one submarginal tuft of hairs on each side situated one third of the way up the lemma body: central aun geniculate. $11-15 \mathrm{~mm}$ long, yellow to brown. loosely twisted basally. kneed about $3 \mathrm{~mm}$ above point of insertion;

\footnotetext{
* National Botanical Institute. Private Bag X|01, Pretoria, (0)0) Present aduress Bolus Herharium. University of Cape Toun. Private Bag. Rondebusch $77(x)$

** Grassland Rexearch Centre, Private Bag X05. Ly nn Fast. Pretoria (0039. MS received: $1990-1) 6-22$
}

palea 4.5-5.5 mm long, narrowly obovate, pubescent in the mid region between the keel and the margin, glabrous between the keels; lodicules 2, up to $1,8 \mathrm{~mm}$ long, with a distinct waist, extending around and beyond the ovary, apically ciliolate; anthers up to $2,75 \mathrm{~mm}$ long; ovary ellipsoid, glabrous.

TYPE. - Cape. 3319 (Worcester): Groot Winterhoek Wilderness area, NW of Groen Mt., Suurvlakte plateau, (-AA), 17-XI-1987, Ellis 5500 (PRE, holo.!). Figure 1.

First collected in 1987, $M$. setacea is so far known from only two localities (Figure 2).

\section{Specimens examined}

CAPE - 3219 (Wupperal): Skurweberge (-CD). Blinkberg Pass. Ellis 5520. 3319 (Worcester): Groot Winterhoek (-AA), Suurvlakte plateau, Ellis 5499. 5500 .

\section{MORPHOLOGY OF MERXMLELLERA SETACEA}

Merxmuellera setacea is quite distinct from all other members of the genus in that it has basally thickened and swollen sheath bases covering the rhizome and axillary buds (Figures 1: 3A, B). The internal tissue of the thickened sheath is pithy in nature and the abaxial surface is glabrous to glossy. The short leaf blades (up to $150 \mathrm{~mm}$ in length) are permanently infolded and setaceous, hence the specific epithet. Three other species of Merxmuellera have swollen basal parts: $M$. rufa (Nees) Conert, $M$. lupulina (Thunb.) Conert and $M$. decora (Nees) Conert. However, in these three species, the basal sheaths are densely villous, and unthickened.

The unusual growth form of this species, a linear series of bulb-like structures, appears to occur as a result of the rhizomes producing numerous closely spaced shoots. These shoots develop beneath the soil surface, producing leaves and occasionally flowering culms. The 


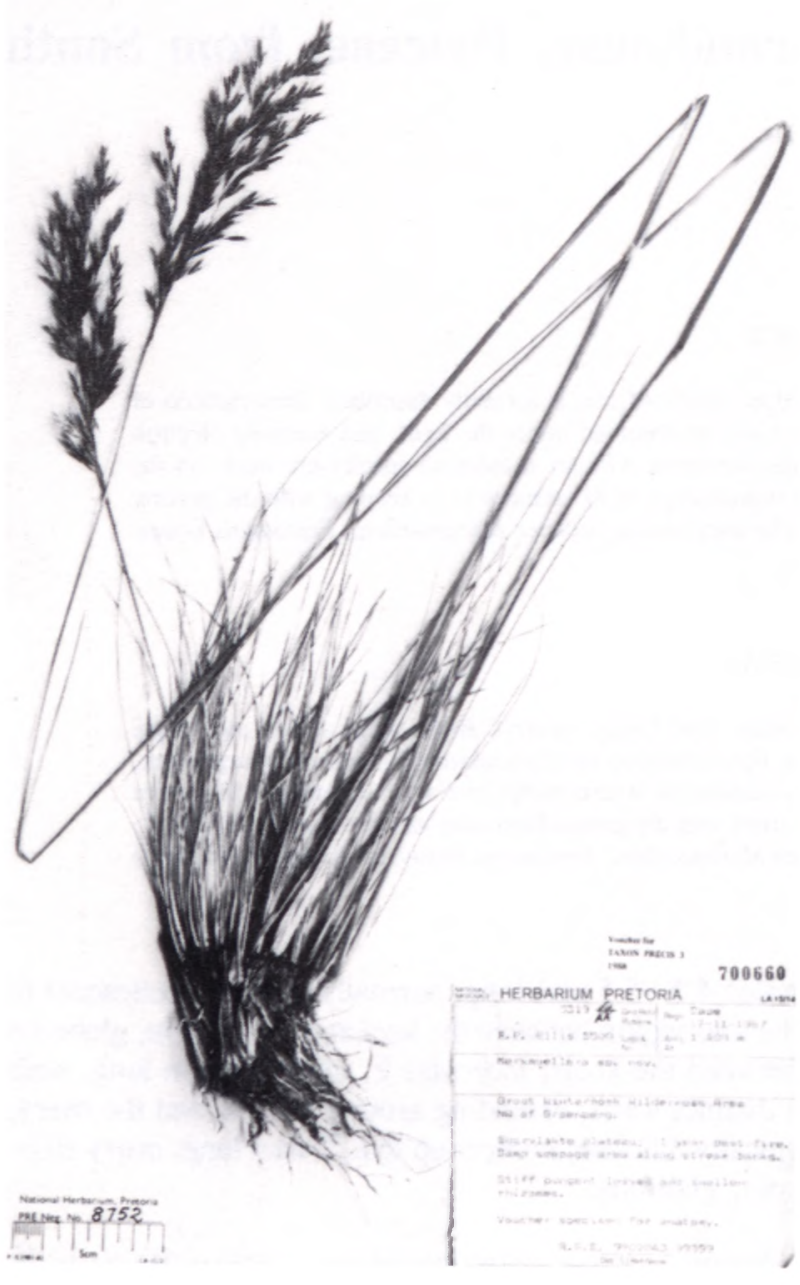

FIGURE 1.-Holotype of Merxmuellera setacea (PRE): short, basal, setacous leaves, swollen culm base and rhizome covered in glabrous papery scales. This specimen bears a label with the words 'Voucher specimen for TAXON PRECIS 3 1988' on it, indicating it was cited as a voucher specimen in Grasses of southern Africa (Gibbs Russell et al. 1990).

basally thickened leaf sheaths overlap each other, producing a bulb-like structure unique to this species. The close proximity of growth points along the rhizome, all developing as described above, produce a line of 'bulbs' beneath the soil surface, and a crest- or hedge-like growth of leaves above the soil surface.

$M$. setacea also has a distinct floral morphology. The lemma has one tuft of long, white, submarginal hairs on each side of the lemma body (Figure 4C). The only other species in the genus with a somewhat similar arrangement of hairs is $M$. dura (Stapf) Conert, which can be distinguished from $M$. setacea not only by the morphology of the basal leaf sheaths but also by differences in other floral characters, such as glume venation (glumes 3-5-nerved in $M$. dura, 1-nerved in $M$. setacea), and the lemma indumentum $(M$. dura has an additional tuft or fringe of hairs around the central awn base, particularly visible on the inner side of the lemma, which is not present in $M$. setacea).

From observations made in the field, it appears that $M$. setacea only grows in very damp to waterlogged soil in seepage areas and streambanks. This waterlogging appears to be seasonal, as all sites where the plant was collected had a very shallow soil layer overlying bedrock, and would dry out rapidly between rainfall events. This species, therefore, probably functions most of the time as a xerophyte in a lithophytic community. The sclerophyllous anatomy of the leaf blade, which is permanently infolded and setaceous, is in keeping with a xerophyte rather than a hydrophyte, which would have soft, spongy, mesophytic leaves with lacunae.

It appears that this species, like several other Cape fynbos grass taxa, survives underground as a geophyte during the protracted interfire periods. During these periods, which may endure for four to 40 years with a mean of 15 years (Van Wilgen 1987), the woodier elements of the vegetation exclude the herbaceous taxa, including the grasses.

This particular interfire survival strategy is typical of a number of Cape fynbos grass taxa, which have all developed swollen, geophytic basal parts (Linder \& Ellis $1990 \mathrm{~b})$. The geophytic base may also protect the innovation bud against fire and desiccation. In the period subsequent to a burn, this geophytic base regenerates vigorously from the rhizomes, producing the growth form described above.

The generic placing of the new species posed problems: the only other southern African arundinoid genera which have species with tufts of hairs on the lemma, although not in the pattern reported here for $M$. setacea, are species of Dregeochloa Conert, Karroochloa Conert \& Türpe, Schismus Beauv. and Centropodia Reichenb.

A position for this new taxon in Karroochloa was rejected as the spikelets of $M$. setacea are too large, far exceeding the 4-7 mm described in Karroochloa (Conert \& Türpe 1969); the glumes of species in Karroochloa are described as being 3-5(-7)-nerved, those of $M$. setacea are 1-nerved. Species of the genus Schismus do not have lemmas with a central, geniculate awn (Conert 1971); the spikelet size and glume venation differ markedly, and consequently this genus was also rejected for the new taxon.

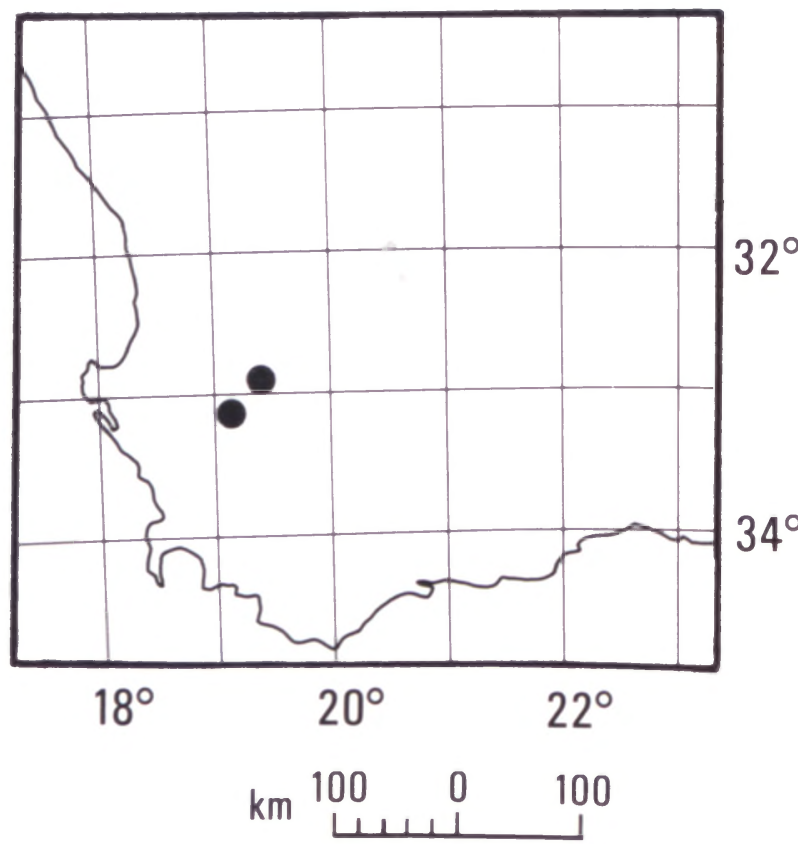

FIGURE 2. - The known distribution of Merxmuellera setacea. 


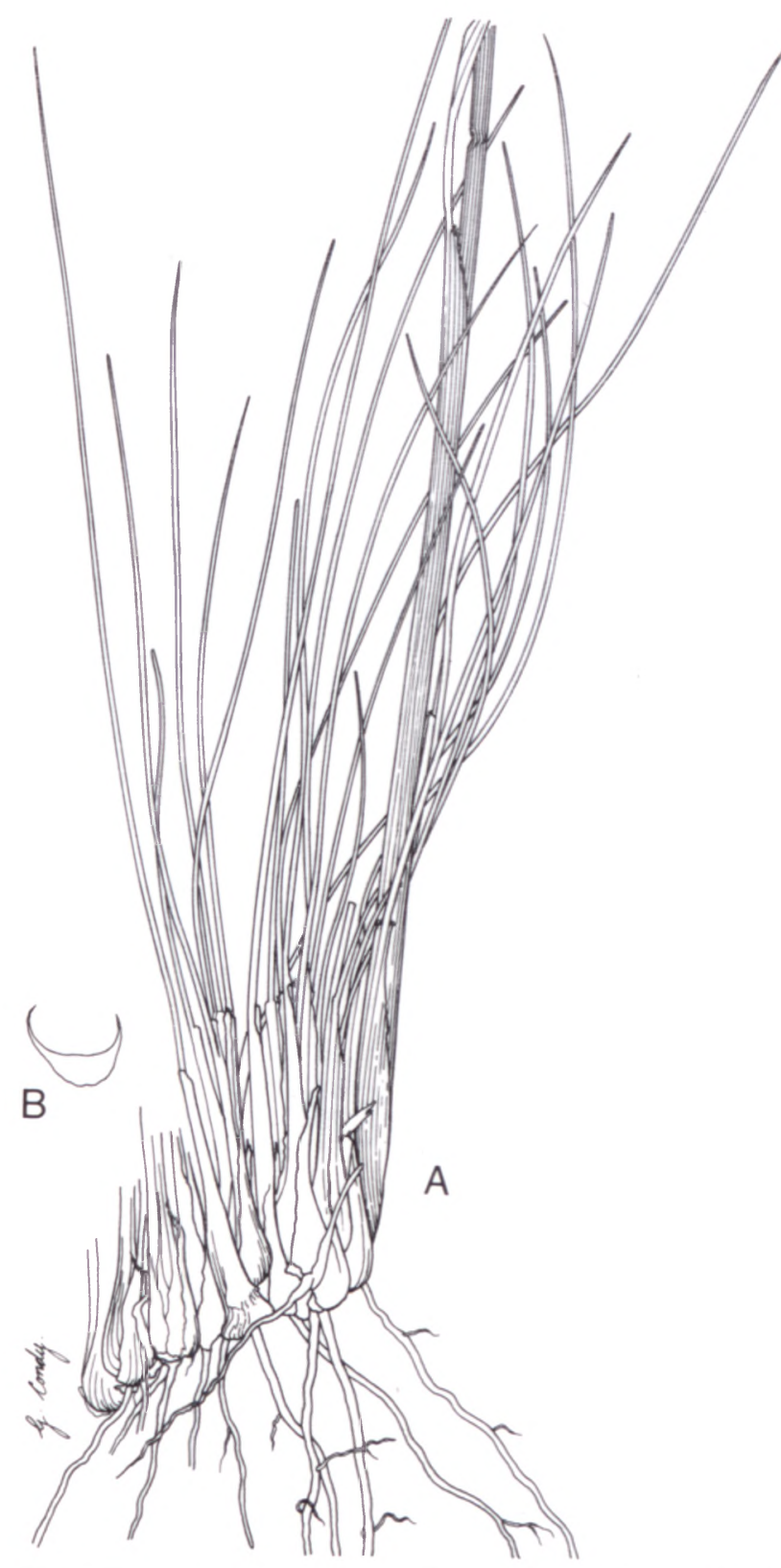

FIGURE 3. - Basal part of Merxmuellera setacea: A, the short, basal, setaceous, pungent leaves arising from swollen culm base, covered in glabrous, papery scales, $\times 0,7 ; \mathrm{B}$, outline of a transverse section through thickened, swollen basal region of leaf sheath, $\times 1,35$.

Species of Dregeochloa, particularly D. calviniensis Conert, bear a superficial resemblance to $M$. setacea in a number of characters: the basal parts are swollen in both taxa (although the rhizome is covered by papery scales and not by swollen sheath bases in $D$. calviniensis); the spikelets are of comparable size, and the leaf blades are short and setacous in both taxa. However, the differences in glume venation (3-5-nerved in $D$. calviniensis); questionable homology between the basal structures of these two species and marked differences in the leaf anatomy of Dregeochloa (Ellis 1977) and M. setacea, made the placing of $M$. setacea in Dregeochloa extremely doubtful.

Centropodia, too, was deemed to be a very poor position for the new taxon, because the lemmas of the taxa of this genus have a transverse row of tufts of hairs across the lemma backs and wide, flat or rolled leaf blades. In addition to this, anatomical evidence of any similarity between $M$. setacea and Centropodia is negligible, as Centropodia has $\mathrm{C}_{4}$ leaf blade anatomy, whereas all other
South African representatives of the Arundineae have $\mathrm{C}_{3}$ anatomy (Ellis 1984, 1989).

Because of the presence of tufts of hairs on the lemma of the new species, neither Pentaschistis nor Pentameris were considered, despite the fact that both these genera have species with 1-nerved glumes, and all taxa in these

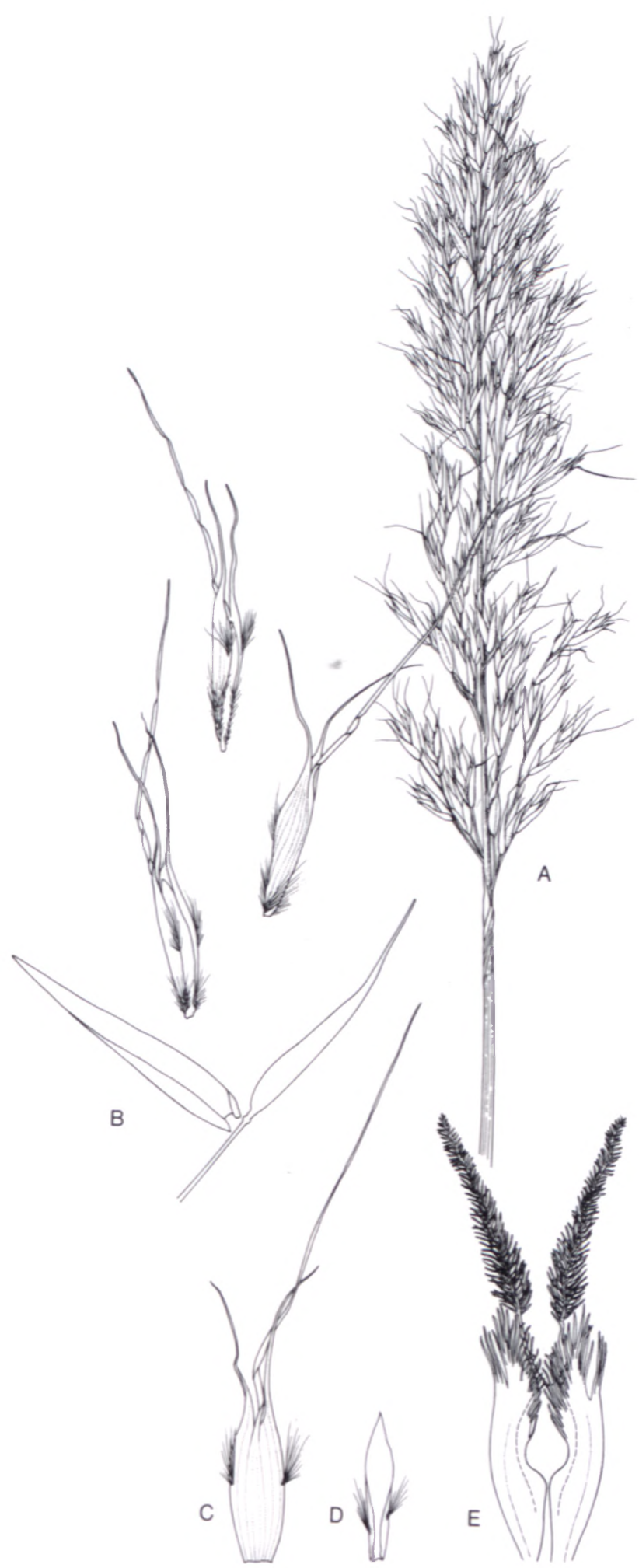

FIGURE 4.-Merxmuellera setacea. A, inflorescence, $\times 1$; $\mathrm{B}$, view of exploded spikelet showing the 1-nerved glumes and three florets, $\times 4$; C, lemma showing the lateral bristles, geniculate central awn and submarginal tufts of hairs, $\times 4 ; \mathrm{D}$, palea showing pubescence between margins and keels, $\times 4$; E, diagram of lodicules, showing pronounced 'waist' and ciliolate apex. Lodicules cover and extend beyond ovary, the outline of which is indicated by the regular dotted line, $\times 40$. 
two genera have 1-2-flowered spikelets (Linder \& Ellis 1990a; Gibbs Russell et al. 1990). A position in Merxmuellera was chosen as this genus has spikelets with 3-10 florets, variously nerved glumes and lemmas which are irregularly pilose or with hairs arranged in tufts, and a central awn which is usually geniculate, $8-20 \mathrm{~mm}$ in length (Conert 1970, 1971).

\section{LEAF ANATOMY OF MERXMUELLERA SETACEA}

The leaf blade anatomy of all the South African species of Merxmuellera has been described (e.g. Ellis 198la, b). In order to obtain further evidence relating to the taxonomic position of the new taxon, a detailed anatomical study of $M$. setacea was carried out for comparison with that of other species of Merxmuellera.

\section{Leaf blade in transverse section}

Outline: permanently infolded, setaceous blade with a reduced $\mathrm{U}$ - or elliptical shape. Adaxial channel deep and narrow. Two halves of leaf lamina not symmetrical about the median vascular bundle (Figure 5A, B) but differ in length and shape of the margins. Ribs and furrows: well developed adaxial ribs and furrows present; furrows deep, cleft-like and located between all larger vascular bundles but occurring irregularly over some of the smaller bundles (Figure 5C-F); ribs rounded, often with flattened tops, and tending to the massive type, present over all larger vascular bundles. No abaxial ribs and furrows.

Median vascular bundle: not structurally distinct from other first order bundles; located off centre in the blade due to asymmetrical nature of laminae (Figure 5A, B). Vascular bundle arrangement: 5 first order bundles alternate with single third order bundles; pattern variable in margin where one first order bundle is much reduced in size and an additional third order bundle may be present on one side of median bundle (Figure 5B); this results in asymmetrical laminae. First order bundles centrally located in the blade but the third order bundles are situated much closer to the abaxial surface (Figure 5C-F).

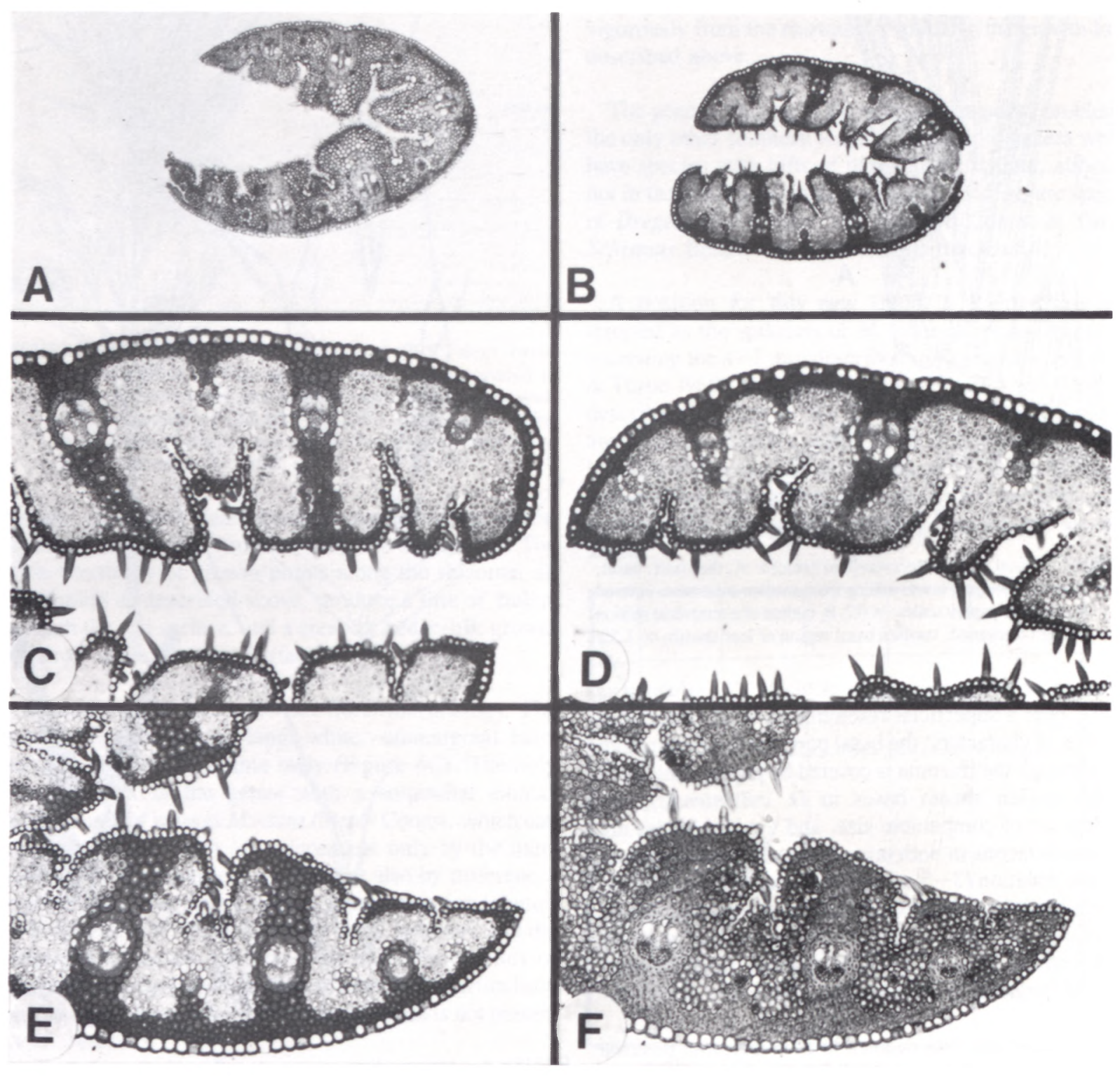

FIGURE 5. - Transectional leaf blade anatomy of Merxmuellera setacea. A, permanently infolded blade with asymmetrical laminae; B, asymmetrical outline without discernible midrib; C, abrupt, truncated margin of blade; D, other margin of same blade as in C, tapering and not truncated; note prickles on adaxial surface. E-F, leaf blade viewed with different filters: E, green filter showing darkly stained, lignified supporting tissue, note the continuous hypodermal sclerenchyma layer connected to the vascular bundles by girders, and the darkly staining, lignified inner and outer bundle sheath cells associated with the first order vascular bundles; F, red filter showing compact mesophyll tissue consisting of small, angular chlorenchyma cells. Ellis vouchers: A, E, F, 5520; B, C, D, 5499. A, B, × 100; C, D, E, F, × 250 


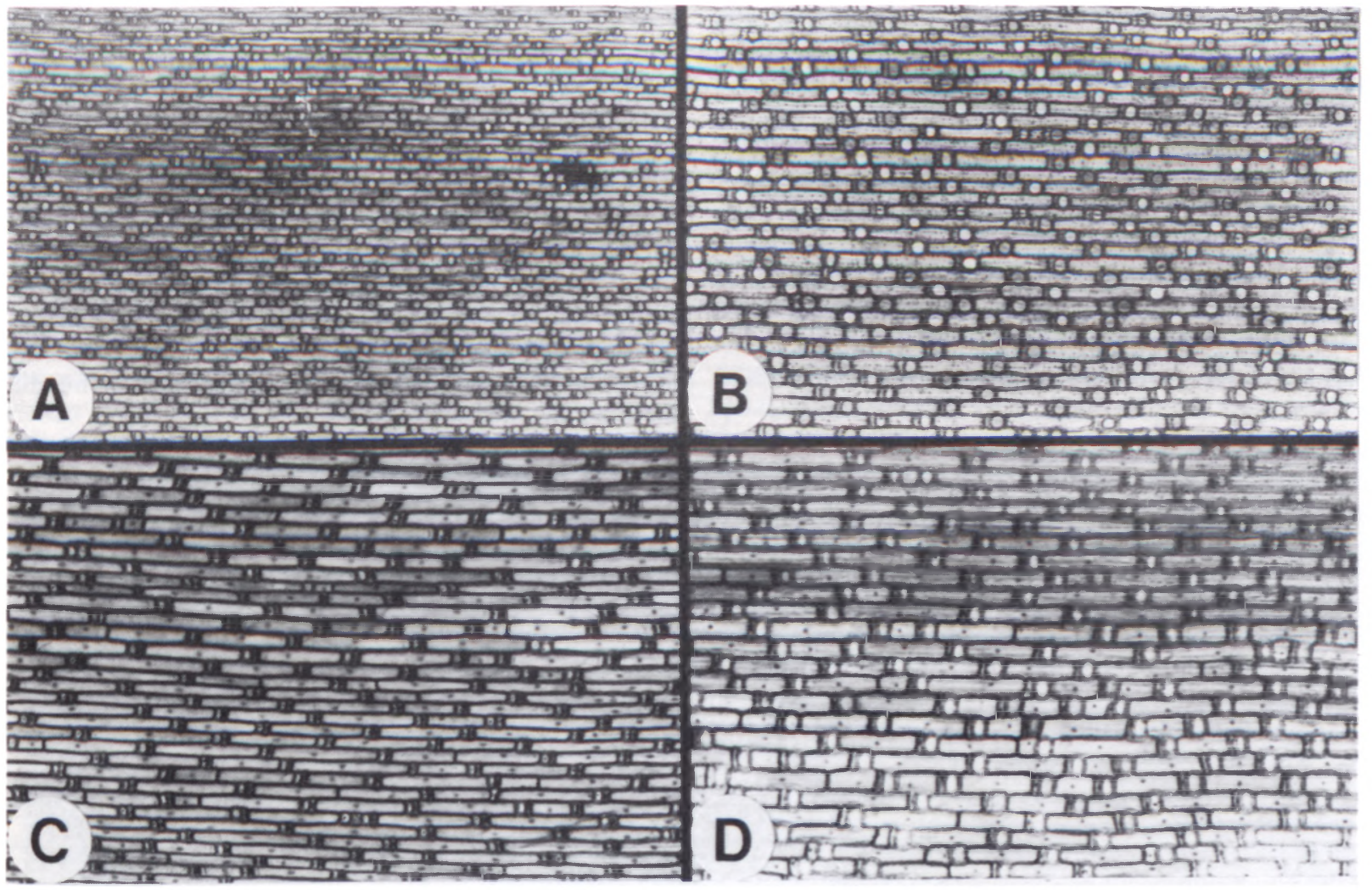

FIGURE 6. - Abaxial epidermis of Merxmuellera setacea. A, epidermal pattern at low magnification showing absence of zonation; B, alternating files of slightly fusiform long cells separated by cork-silica cell pairs, circular silica bodies closely associated with tall cork cell; C, very uniform arrangement of costal long and short cells; D, consistent pattern of epidermal cell arrangement and form. Ellis vouchers: A, B, 5520; C, 5499; D, 5500. A, × 160; B, C, D, $\times 250$.

Vascular bundle description: third order bundles elliptical with xylem and phloem tissue indistinguishable. First order bundles elliptical with narrow metaxylem vessels with unthickened secondary walls. Sclerosed phloem divided by intrusive fibres present (Figure 5C-F). Vascular bundle sheaths: first order bundle outer sheaths elliptical with wide adaxial and abaxial interruptions; cells elliptical, small (same size as the innner sheath cells) with thin walls (Figure 5C, D) but often with distinctly thickened walls (Figure 5E, F) which then structurally resemble mestome sheath cells. Inner sheath complete, consisting of relatively large cells with heavily but uniformly thickened walls. Third order bundles without adaxial interruptions and without thickened outer bundle sheath cells (Figure 5E, F).

Sclerenchyma: adaxial girders associated with the first order vascular bundles inversely anchor-shaped with long, tall and multiseriate stems; abaxial girders well developed and trapezoidal in shape; associated with first and third order bundle; laterally fused, forming continuous abaxial hypodermal fibrous layer. All fibres with very thick, lignified secondary walls and no sclerenchyma tissue staining blue-green with fast green (Figure 5F). Chlorenchyma: irregular arrangement, W-shaped mesophyll tissue occupying the sides and bases of furrows; tissue consisting of small, regular isodiametric cells which are tightly packed with very small intracellular air spaces (Figure 5F). Colourless cells: absent. Adaxial epidermal cells: bulliform cells very small, located at bases of furrows. No macro-hairs or papillae; prickle hairs with long barbs common, these without bulbous bases. Abaxial epidermal cells: no bulliform cells or appendages. Continuous, thick cuticle present over uniform, but small epidermal cells.

\section{Abaxial epidermis in surface view}

Zonation: costal and intercostal zones not distinguishable (Figure 6A). Long cells: elongated, rectangular with side walls parallel or slightly bowed, slightly thickened, not undulate (Figure 7A, B). Nuclei present (Figure 6B-D). Cell shape and size consistent throughout epidermis (Figure 6A). Short cells: cork-silica cell pairs alternate with all long cells in all files. Silica cells closely associated with tall cork cell (Figure 6D). Stomata: absent. Papillae: absent. Prickles: absent. Microhairs: absent. Macrohairs: absent. Silica bodies: round to slightly elliptical (Figure $6 \mathrm{~B}-\mathrm{D} ; 7 \mathrm{~B})$; present throughout the epidermis; same width as long cells.

\section{Adaxial epidermis in surface view}

Long cells: elongate, rectangular without sinuous walls (Figure 7C). Short cells: appear to be absent. Stomata: low dome-shaped, flush with the epidermal surface (Figure $7 \mathrm{E}, \mathrm{F})$; restricted to the bases and sides of the adaxial furrows. Papillae: absent. Prickles: common with long barbs and without swollen bases (Figure 7C, D); prickles on top of adaxial ribs with blunt apices, whereas those overlying the furrows interlocking with sharp, long barbs (Figure 7C). Microhairs: elongate, at least 3 times the length of the stomata; basal cell very long and narrow with minute distal cell only ${ }^{1 / 5}$ the length of the hair (Figure $7 \mathrm{E}, \mathrm{F})$; only present in adaxial furrows. Macrohairs: absent. Silica bodies: appear to be absent.

The leaf anatomy of $M$. setacea is unusual in several respeçts and does not closely resemble that of any other species of Merxmuellera. Certain anatomical similarities 
with some species of Pentaschistis and Pentameris are, however, evident.

The asymmetrical leaf outline of $M$. setacea, together with the off-centre location of the median vascular bundle, is an unusual feature, but one that is not unique in the tribe. Similar outlines rarely occur in $M$. aureocephala (J.G. Anders.) Conert (Ellis 1981b), Pentaschistis pyrophila Linder and $P$. eriostoma (Nees) Stapf (Ellis \& Linder in prep.). This feature in isolation does not appear to be taxonomically important but it is always associated with other anatomical attributes which appear to link $M$. setacea to these other taxa and their close relatives.
One such feature is the alternating arrangement of first and third order vascular bundles across the leaf width. This pattern is not found in M. stricta (Schrad.) Conert and its allies (Ellis 1981b) where lateral first order bundles are not separated by smaller bundles. $M$. dura also has this $M$. stricta type of vascular bundle arrangement. Thus the similarities between $M$. setacea and $M$. dura as suggested by the lemma vesture are not supported by the vascular bundle arrangement observed in these two species. $M$. disticha (Nees) Conert, M. davyi (C.E. Hubb.) Conert, M. macowanii (Stapf) Conert and sometimes M. aureocephala, however, share the alternating vascular bundle arrangement with $M$. setacea.

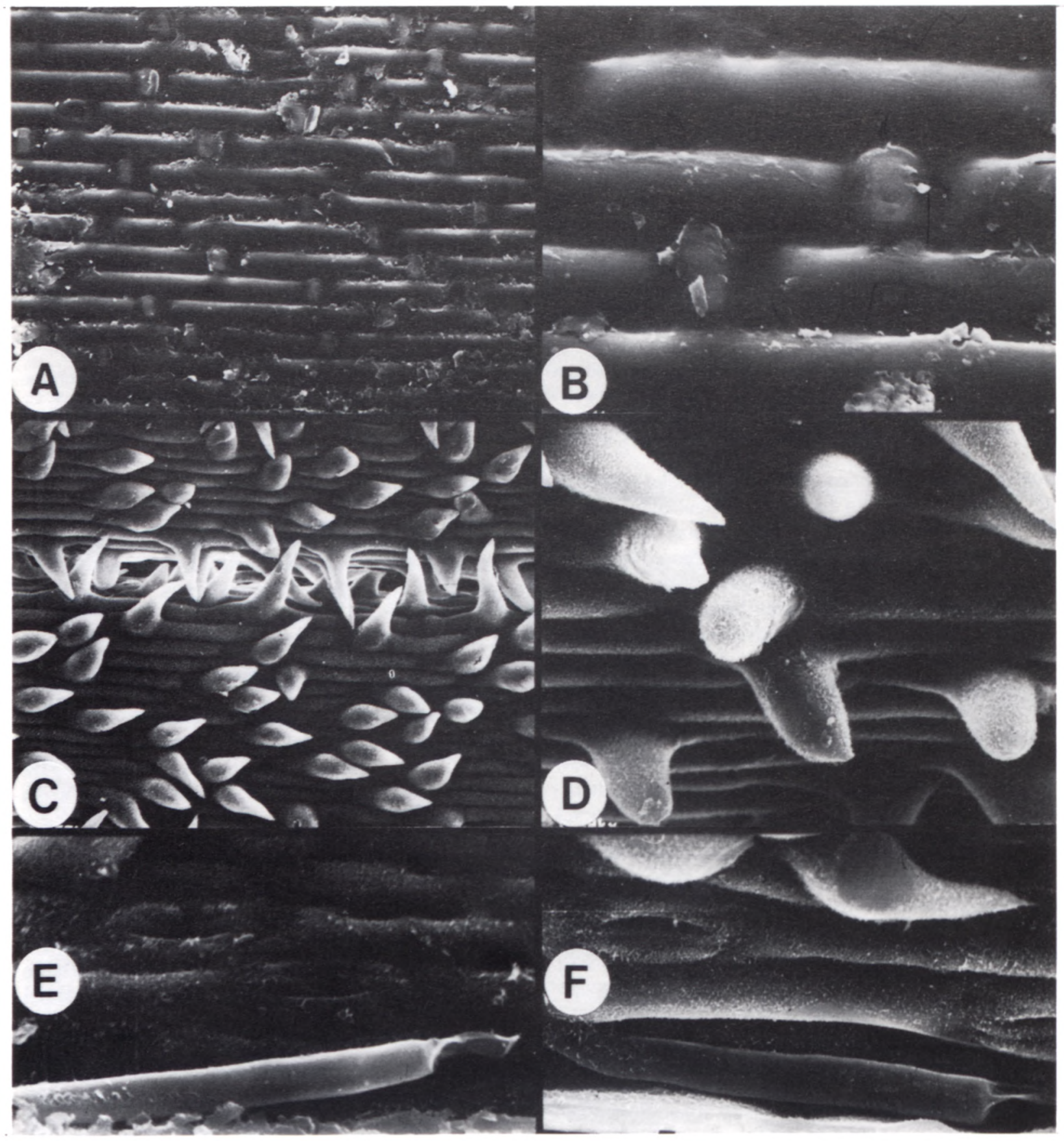

FIGURE 7.-Epidermal ultrastructure of Merxmuellera setacea. A, B, abaxial epidermis: A, uniform arrangement of rectangular long cells alternating with paired silica bodies and cork cells. This pattern is consistent along all epidermal cell files, note the absence of epidermal appendages; B, detail of rectangular to slightly fusiform long cells with inflated anticlinal walls and thickened periclinal walls, silica bodies oval to round in shape. C, D, adaxial epidermis: C, elongated prickle hairs common, interlocking over adaxial groove and resembling asperites on adaxial ribs; D, detail of prickles showing barbed prickles on sides of adaxial rib, whereas those on the top of the rib tend to be domed. E, F, adaxial microhairs located on the sides and bases of the cleft-like furrows: E, elongated microhair with basal cell considerably longer than the small cap cell; F, apical cell only $1 / 5$ the length of the elongated basal cell, note stomata located at the base of the furrow beneath the interlocking prickles. Ellis vouchers: A, B, E, 5499; C, D, F, 5500. A, C, $\times 200$; B, D, E, F, $\times 650$. 
A similar alternating arrangement of vascular bundles occurs in most species of Pentameris, particularly $P$ macrocalycina (Steud.) Schweick. and Pentameris sp. 1 sensu Barker in Gibbs Russell et al. (1990) [ = P. obtusifolia (Hochst.) Schweick. sensu Ellis 1985)] as well as many species of Pentaschistis (Ellis \& Linder in prep.). Relevant examples are $P$. pyrophila, $P$. eriostoma and $P$. curvifolia (Schrad.) Stapf and its allies.

The sclerosed phloem in $M$. setacea occurs in $M$. macowanii, $M$. davyi and $M$. aureocephala (Ellis 1981b) but not in $M$. disticha. This feature also occurs in $M$. stricta (very rarely), M. drakensbergensis (Schweick.) Conert and $M$. stereophylla (J.G. Anders.) Conert (Ellis 1981a), but these latter species do not have the same vascular bundle arrangement as $M$. setacea. Intrusive fibres also do not occur in either Pentameris or Pentaschistis. This feature is, therefore, not congruent with the evidence from other anatomical characters, but does support the placement of $M$. setacea in Merxmuellera rather than either Pentameris or Pentaschistis.

The secondary thickening of the walls of the outer bundle sheath cells of $M$. setacea appears to be a unique feature in South African arundinoid species, but was only observed in the first order vascular bundles of the type specimen, Ellis 5500) (Figure 5E, F). Other specimens from the same locality (Ellis 5499), as well as from elsewhere. lacked this feature. Secondary wall thickening of outer bundle sheath cells is therefore, not a consistent feature of this species and merits little taxonomic significance.

The lignified fibres of the sclerenchyma of $M$. setacea. together with the continuous hypodermal sclerenchyma layer, are another feature this species shares with those species also possessing the same type of bundle arrangement. However, similar sclerenchyma also occurs in $M$. drakenshergensis and M. stereophylla (Ellis 1981a) which have the $M$. stricta type of bundle arrangement.

The unusual epidermal features of adaxial prickles and the extremely elongate microhairs of $M$. setacea appear to be very significant in the classification of this species. These features are closely correlated with many of the features of the transectional anatomy discussed above. $M$. stricta and its allies have a papillate adaxial epidermis and the microhairs are short with basal and distal cell equal in length. This type of hair may also occur on the abaxial surface. Even where adaxial prickles are present (as in $M$. drakensbergensis and $M$. stereophylla) these differ considerably from those of $M$. setacea in that they are closely surrounded by raised intlated papillae. $M$. setacea therefore differs considerably from $M$. stricta. $M$. guillarmodiae Conert, $M$. drakensbergensis, $M$. stereophylla. and even $M$. dura which resembles this group of species very closely. This type of papillate epidermis and short microhair in turn also occurs in Pentaschistis colorata (Steud.) Stapf and closely allied Pentaschistis species (Ellis \& Linder in prep.).

Arundinoid species which also have elongated adaxial microhairs with minute distal cells and adaxial prickles are: Pentameris macrocalvcina. Pentameris sp. I (sensu Barker in Gibbs Russell et al. 1990). P. thuarii Beauv. and P. longiglumis (Nees) Stapf as well as Pentaschistis pyrophila Linder, $P$. eriostoma (Nees) Stapf and $P$ curvifolia (Schrad.) Stapf. and its close allies ( $P$. pungens Linder, $P$. caulescens Linder, $P$. scandens Linder and $P$. acinosa Stapf).

\section{CONCLUSIONS}

The inclusion of $M$. setacea in the Arundinoideae is fully supported by the leaf anatomical evidence although this subfamily lacks reliable diagnostic features (Ellis 1986). The presence of microhairs precludes pooid relationships (Watson et al. 1985). This is supported by the dome-shaped stomata with guard cells flush with the epidermis and the absence of oblong or nodular silica bodies (Ellis 1986). The non-Kranz anatomy with compact chlorenchyma, simple midrib, absence of papillae and the elongated, finger-like microhairs, in combination, also suggest arundinoid affinities. Within this subfamily this suite of anatomical characters also supports the classification of $M$. setacea in the tribe Arundineae and excludes its inclusion in any of the other tribes.

The lack of congruence between anatomical characters, such as the asymmetrical leaf outline, the arrangement of first and third order vascular bundles and various adaxial epidermal features, and the generic classification of these taxa appears to be a reflection of the unsatisfactory delimitation of the arundinoid genera Merxmuellera, Pentaschistis and Pentameris.

Anatomical evidence indicates affinities for $M$. setacea with certain species of Merxmuellera, together with other species presently included in both Pentameris and Pentaschistis, and the new taxon appears to be truly intermediate in its leaf anatomy, making it particularly valuable in gaining a better understanding of the complex character distribution patterns exhibited by these taxa. Individual anatomical characters show clear disjunctions but, in combination, no reliable diagnostic differences appear to separate the various taxa displaying resemblances to $M$. setacea.

Before the taxonomic significance of these indications can be fully appreciated. it will be necessary to undertake an extensive evaluation of as many characters as possible in order to arrive at a more natural delimitation of genera in this poorly understood tribe. The correct taxonomic placement of this new species is therefore extremely difficult. Thus, although the true affinities of this species are obscure, its identification and description will undoubtedly contribute to a better understanding of the complex interrelationships between these arundinoid genera. It therefore seems reasonable to follow the spikelet indications and include this new species in Merxmuellera until such time as generic delimitations in this tribe become clearer.

\section{ACKNOWLEDGEMENTS}

We would like to thank Ms G. Condy for the pen and ink art work, Mrs S.M. Perold for assistance with the SEM work. Mrs A. Romanowski for the preparation of the photographic figures and Dr H.F. Glen for the Latin translation. 


\section{REFERENCES}

CONERT, H.J. 1970. Merxmuellera, eine neue Gattung der Gramineen (Poaceae. Arundinoideae). Senckenbergiana Biologica 51 $129-133$.

CONERT, H.J. 1971. The genus Danthonia in Africa. Mitteilungen der Botanischen Staatssammlung, München 10: 299-308.

CONERT. H.J. \& TÜRPE. A.M. 1969. Karroochloa, eine neue Gattung der Gramineen (Poaceae. Arundinoideae, Danthonieae). Senckenbergiana Biologica 50: 289-318.

ELLIS, R.P. 1977. Leaf anatomy of the South African Danthonieae (Poaceae). I. The genus Dregeochloa. Bothalia 12: 209-213.

ELLIS, R.P. 1981a. Leaf anatomy of the South African Danthonieae (Poaceae). IV. Merxmuellera drakensbergensis and $M$. stereophyla. Bothalia 13: 487-491

ELLIS. R.P. 198lb. Leaf anatomy of the South African Danthonieae (Poaceae). V. Merxmuellera macowanii, $\boldsymbol{M}$. davi and $M$. aureocephala. Bothalia 13: 493-500.

ELLIS, R.P. 1984. Leaf anatomy of the South African Danthonieae (Poaceae). IX. Asthenatherum glaucum. Bothalia 15: 153-159.

ELLIS, R.P. 1985. Leaf anatomy in the South African Danthonieae (Poaceae). XIII. Pentameris macrocalycina and P. obtusifolia. Bothalia 15: $579-585$.

ELLIS, R.P. 1986. A review of comparative leaf blade anatomy in the systematics of the Poaceae: the past twenty-five years. In T.R
Soderstrom et al., Grass systematics and evolution. Smithsonian Institution Press, Washington D.C.

ELLIS, R.P. 1989. Leaf anatomy of the South African Danthonieae (Poaceae). XVIII. Centropodia mossamedensis. Bothalia: 19: $4 I-44$.

ELLIS. R.P. \& LINDER. H.P. in prep. An atlas of leaf anatomy in the genus Pentaschistis (Poaceae: Arundinoideae: Arundineae). Memoirs of the Botanical Survey of South Africa.

GIBBS RUSSELL, G.E., WATSON, L., KOEKEMOER, M., SMOOK. L., BARKER, N.P., ANDERSON, H.M. \& DALLWITZ. M.J. 1990. Grasses of southern Africa. Memoirs of the Botanical Survey of South Africa No. 58: 1-437.

LINDER, H.P. \& ELLIS, R.P. 1990a. A revision of Pentaschistis (Arundineae, Poaceae). Contributions from the Bolus Herbarium No. 12

LINDER. H.P. \& ELLIS, R.P. 1990b. Vegetative morphology and interfire survival strategies in the Cape Fynbos grasses. Bothalia 20: 9l-103.

VAN WILGEN. B.W. 1987. Fire regimes in the fynbos biome. In R.M. Cowling et al., Disturbance and the dynamics of funbos biome communities. South African National Scientific Programmes Report No. 135. CSIR. Pretoria.

WATSON, L., CLIFFORD, H.T. \& DALLWITZ, M.J. 1985. The classification of Poaceae: subfamilies and supertribes. Australian Journal of Botany 33: 433-484 